This item is the archived peer-reviewed author-version of:

Dynamic risk analysis for Seveso sites

\title{
Reference:
}

Paltrinieri Nicola, Reniers Genserik.- Dynamic risk analysis for Seveso sites

Journal of loss prevention in the process industries - ISSN 0950-4230 - 49:A(2017), p. 111-119

Full text (Publisher's DOI): https://doi.org/10.1016/J.JLP.2017.03.023

To cite this reference: https://hdl.handle.net/10067/1444720151162165141 


\section{Dynamic risk analysis for Seveso sites}

Nicola Paltrinieria ${ }^{a}$, Genserik Reniers ${ }^{b, c, d}$

a Norwegian University of Science and Technology NTNU, Department of Process and Quality Engineering, Trondheim, Norway

${ }^{b}$ Faculty of Applied Economics, University of Antwerp Operations Research Group ANT/OR, Antwerp, Belgium

${ }^{c}$ Center for Corporate Sustainability (CEDON), HUB, KULeuven, Brussels, Belgium

d Safety Science Group, TU Delft, Delft, the Netherlands

\section{Keywords}

Dynamic risk analysis; Seveso site; DyPASI; Risk Barometer; Thermal Risk Index. 


\section{Introduction}

In 1976, a major accident occurred in a small chemical plant in Seveso (near Milan, Italy) changed our approach to risk assessment forever. Dispersed dioxin into the local atmosphere and environment, as a result of pressure relief venting following a reactor runaway accident, led to skin disease chloracne in about 250 people and caustic soda burns in about 450 people. A large are of land, about $17 \mathrm{~km}^{2}$, was contaminated and about $4 \mathrm{~km}^{2}$ was made uninhabitable [1].

This led to drafting the first Seveso Directive [2], intended both to prevent major hazards and to protect workers and citizens. After almost 40 years, on 1 June 2015, the European Union (EU) member (and associated) states brought into force the laws, regulations and administrative provisions necessary to comply with the EU Directive denominated Seveso III [3]. It replaces the previous Seveso II directive [4] and deals with the control of on-shore major accident hazards involving dangerous substances. Seveso III responds to the need of ensuring appropriate precautionary actions for high level of protection for citizens, communities and the environment throughout the Union [3].

Operators of sites where hazardous substances are handled should take all the necessary measures to prevent major accidents, mitigate their consequences and recovery from them. Such establishments range from explosive storage facilities and fuel and gas depots to complex process industries. They are

denominated "Seveso sites" (further categorized in lower- and upper-tier establishments). The directive defines hazardous substances and quantity thresholds for lower and upper tiers [3]. The operators have the obligation to provide information to the competent authorities set up by the state, under the form of:

- A major accident prevention policy (MAPP) setting out the operator overall approach, measures (including safety management system) to control major accident hazards.

- A safety report (for upper-tier sites) to demonstrate that all that is necessary has been done to prevent major accidents and prepare emergency plans and response measures. The operator is required to review the safety report at least every five years. 
- Information from inspections to demonstrate that the data and information in the safety report adequately reflect the conditions in the establishment.

- Information to assess the effects on human health and environment of an occurred major accident.

- Information and data at any time if requested.

Some EU member and associated countries have also developed specific methods to regularly collect and monitor such information. This would also allow competent authorities and states to assess risk trends of Seveso sites. However, there is not a consolidated approach for such periodic monitoring. A risk analysis study is usually performed during the design phase or early life of a system and draws a static picture of what its safety measures are. While the system constantly evolves or degrades, the Seveso site safety report is updated approximately every five years - or in case of major accident or inspections by the competent authority, demonstrating that the report does not reflect the conditions of the establishment. For this reason, this contribution suggests a specific approach of dynamic risk analysis aiming to continuously calibrate and improve based on new related evidence and lessons learned from the ever-changing reality.

This work introduces high consequence low probability (HCLP) accidents in Seveso sites and how they may be defined. Focusing on early warnings, deviations and past events is suggested to lower the probability of HCLP events. Such Small Things may be used for risk analysis iteration, in order to progressively improve and refine the evaluated risk picture. The study shows how these last developments represent an improvement of risk analysis, by comparing dynamic risk analysis capabilities with what occurred in the Seveso accident. Finally, generic benefits and limitations of dynamic risk analysis are discussed and conclusions are drawn.

\section{Considering Small Things}

Pasman affirms that events in process industry involving hazardous materials, such as the ones handled in Seveso sites, represent the most dreadful risk [5]. Loss of control of such substances has the 
potential to cause HCLP accidents [5]. High consequence means catastrophic losses, sometimes with huge loss of human life. On the other hand, such events have may have very low probability and may not happen in our lifetime.

Such events have been widely studied and discussed by several recent related works. For instance, Paltrinieri et al. $[6,7]$ defines the concept of "atypical accidents", which may address a aspecific aspect of Pasman's HCLP events. Atypical accidents are event that were "not captured by hazard identification methodologies because deviating from normal expectations of unwanted events or worst case reference scenarios." An atypical accident may occur when hazard identification does not produce a complete overview of system hazards [6,7]. Taleb [8] defines rare catastrophic events that have never been encountered before as Black Swans. According to him, such events can be explained only after the fact and cannot be anticipated. However, Paté-Cornell [9] and Haugen and Vinnem [10] warn against the misuse of the Black Swan concept. This should not be a reason for ignoring potential scenarios or waiting until a disaster happens to take safety measures and issue regulations against a predictable situation. On the contrary, it should represent an incentive to continuously learn and improve.

As an answer to potentially unknown HCLP events, the concept of Dragon-Kings, theorized by Sornette [11], may be of help. "Kings" because such events are extreme and outliers (in analogy with the kings' wealth). "Dragons" because they are unlike anything else, out of the bestiary. The study on DragonKings is rooted in geophysics [12]. In fact, one of the Sornette's earlier works addressed the prediction of earthquakes [13]. He saw that some degrees of organization and coordination could serve to amplify fractures, which are anyway always present and forming in the tectonic plates. Organization and coordination may turn small causes into large effects, i.e. explosive ruptures such as earthquakes, which are characterized by low probability.

Extreme accidents are the result of a particular combination of single events, some of which may be considered as deviations from normal/optimal conditions. Paltrinieri et al. [14,15] firstly define such 
deviations as early warnings, but, lately, Paltrinieri and Khan [16] associate such deviations with the concept of "Small Things". Small things might be recurring old issues in a plant or organization, which do not need imaginative definitions to be prevented, but perhaps only the compliance with already present procedures. Acting on Small Things would allow breaking the chain of events and lower the probability for major unpredictable accidents.

In the last decade, increasing attention has been dedicated to evaluation and monitoring of early deviations through appropriate indicators, as a way to assess and control risk. Indicators can be represented by a series of factors: physical conditions of a plant (equipment pressure and temperature); number failures of an equipment piece; maintenance backlog; number of emergency preparedness exercises; amount of overtime worked; etc. A number of indicator typologies have been theorized and used. Øien et al. [17] affirm that we can refer to risk indicators if: they provide numerical values (such as a number or a ratio); they are updated at regular intervals; they only cover some selected determinants of overall risk, in order to have a manageable set of them. The latter feature has quickly become outdated due to the extensive collection that is being carried out in industry and the attempts made to process and elaborate larger numbers of them. For instance, for the first time since the first Seveso directive was issued in 1982, Seveso III mentions specific procedures for safety performance indicators and/or other relevant indicators, to use for monitoring the performance of safety management systems [3]. Table 1 reports how such suggestion has been received in the EU member and associated countries - Seveso III implementation or work of consultants for the competent authorities are considered. 
Table 1 Characteristics of Seveso monitoring approaches in the EU member and associated countries

\begin{tabular}{|c|c|c|c|c|c|}
\hline \multirow[t]{2}{*}{ Country } & \multicolumn{2}{|c|}{ Indicators } & \multirow{2}{*}{$\begin{array}{c}\text { Further } \\
\text { classification of } \\
\text { Seveso sites }\end{array}$} & \multirow[t]{2}{*}{ Notes } & \multirow[t]{2}{*}{ Ref. } \\
\hline & Past events & $\begin{array}{l}\text { Safety performance } \\
\text { indicators }\end{array}$ & & & \\
\hline 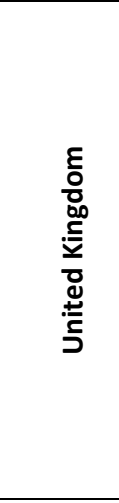 & $\begin{array}{l}\text { Related incidents and } \\
\text { dangerous occurrences are } \\
\text { not only reported to the } \\
\text { competent authorities but } \\
\text { also regulated by RIDDOR } \\
\text { (Reporting of Injuries, } \\
\text { Diseases and Dangerous } \\
\text { Occurrences). The causes of } \\
\text { the reported incidents are } \\
\text { reviewed periodically. }\end{array}$ & $\begin{array}{l}\text { The British competent } \\
\text { authorities (Health and } \\
\text { Safety Executive, } \\
\text { Environment Agency and } \\
\text { SEPA) require all major } \\
\text { hazard establishments and } \\
\text { duty holders to measure } \\
\text { their performance on the } \\
\text { control of major hazard } \\
\text { risks by way of process } \\
\text { safety performance } \\
\text { indicators (PSPIs). }\end{array}$ & $\begin{array}{l}\text { The competent } \\
\text { authorities } \\
\text { employ } \\
\text { prioritisation of } \\
\text { Seveso sites } \\
\text { with respect to } \\
\text { safety of } \\
\text { persons and } \\
\text { environment. } \\
\text { Sites are } \\
\text { classified in four } \\
\text { safety groups } \\
\text { (A-D). }\end{array}$ & $\begin{array}{l}\text { The COMAH } \\
\text { Regulations } \\
2015 \\
\text { implement the } \\
\text { majority of the } \\
\text { Seveso III } \\
\text { Directive in } \\
\text { Great Britain } \\
\text { (Northern } \\
\text { Ireland } \\
\text { produces its } \\
\text { own } \\
\text { regulations). }\end{array}$ & $\begin{array}{l}{[3,18-} \\
22]\end{array}$ \\
\hline 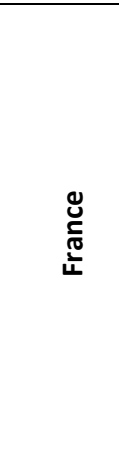 & $\begin{array}{l}\text { Accidents and incidents are } \\
\text { collected in the database } \\
\text { ARIA (Analysis, Research } \\
\text { and Information on } \\
\text { Accidents). The French } \\
\text { Ministry of Ecology at } \\
\text { BARPI (Bureau for Analysis } \\
\text { of Risks and Industrial } \\
\text { Pollution), presents annual } \\
\text { records as incident } \\
\text { indicators and KPIs (Key } \\
\text { Performance Indicators). }\end{array}$ & $\begin{array}{l}\text { The French national } \\
\text { competence centre for } \\
\text { industrial safety and } \\
\text { environmental protection } \\
\text { (INERIS) identified the need } \\
\text { to employ indicators for } \\
\text { industrial safety. A specific } \\
\text { method was defined to } \\
\text { develop, select and use an } \\
\text { appropriate "Safety } \\
\text { Performance Indicator } \\
\text { System" (SIPS). }\end{array}$ & I & $\begin{array}{l}\text { The decrees } \\
2014-284 \text { of } 3 \\
\text { March } 2014 \text { and } \\
2014-285 \text { of } 3 \\
\text { March } 2014 \\
\text { implement the } \\
\text { Seveso III } \\
\text { directive in } \\
\text { France. }\end{array}$ & $\begin{array}{l}{[3,22-} \\
26]\end{array}$ \\
\hline$\frac{7}{ \pm}$ & $\begin{array}{l}\text { Near misses, incidents and } \\
\text { accidents are reported to } \\
\text { the competent authority. }\end{array}$ & $\begin{array}{l}\text { The Italian regulation states } \\
\text { that safety performance } \\
\text { monitoring should be at } \\
\text { least based on the } \\
\text { evaluation of indicators and } \\
\text { their trend. }\end{array}$ & I & $\begin{array}{l}\text { The legislative } \\
\text { decree } 105 \text { of } \\
26 \text { June } 2015 \\
\text { implements the } \\
\text { Seveso III } \\
\text { directive in } \\
\text { Italy. }\end{array}$ & $\begin{array}{l}3,22, \\
27,28]\end{array}$ \\
\hline 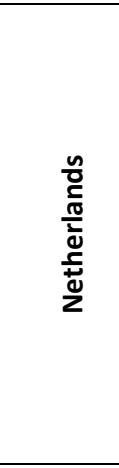 & $\begin{array}{l}\text { A special approach for } \\
\text { collecting accidents } \\
\text { involving dangerous } \\
\text { substances in Seveso sites } \\
\text { was developed. It is } \\
\text { designed for the Major } \\
\text { Hazard Control Directorate } \\
\text { of the Labour Inspectorate. } \\
\text { The database involves } \\
\text { about } 260 \text { accidents that } \\
\text { occurred in the period } \\
2004-2013 \text {. }\end{array}$ & $\begin{array}{l}\text { The new Dutch decree } \\
\text { introduces the use of } \\
\text { indicators providing } \\
\text { information on the safety } \\
\text { performance of a company } \\
\text { handling hazardous } \\
\text { substances. The Dutch } \\
\text { National Institute for Public } \\
\text { Health and the } \\
\text { Environment (RIVM) has } \\
\text { drawn up a guidance for } \\
\text { use of such indicators. }\end{array}$ & / & $\begin{array}{l}\text { The decree Brzo } \\
\text { (Besluit risico's } \\
\text { zware } \\
\text { ongevallen) } \\
2015 \\
\text { implements the } \\
\text { Seveso III } \\
\text { directive in the } \\
\text { Netherlands. }\end{array}$ & $\begin{array}{l}{[3,22,} \\
29,30]\end{array}$ \\
\hline$\frac{\text { }}{\frac{0}{\pi}}$ & $\begin{array}{l}\text { The Finnish Safety } \\
\text { Technology Authority } \\
\text { (TUKES) uses accidents, } \\
\text { near-miss cases, fault and } \\
\text { failure lists to assess the } \\
\text { performance of safety } \\
\text { management systems. }\end{array}$ & $\begin{array}{l}\text { Other indicators are used } \\
\text { to assess the performance } \\
\text { of safety management } \\
\text { systems: investments } \\
\text { regarding safety, } \\
\text { cleanliness level, general } \\
\text { tidiness, good order, } \\
\text { follow-up of recorded } \\
\text { faults, safety tours, follow- } \\
\text { up of safety level statistics } \\
\text { are used as indicators. }\end{array}$ & $\begin{array}{l}\text { Seveso sites are } \\
\text { classified based } \\
\text { on legislative, } \\
\text { technical, } \\
\text { operational and } \\
\text { organizational } \\
\text { elements. }\end{array}$ & $\begin{array}{l}\text { The } \\
\text { government } \\
\text { decree } 685 \text { of } \\
21 \text { May } 2015 \\
\text { implements the } \\
\text { Seveso III } \\
\text { directive in } \\
\text { Finland. }\end{array}$ & $\begin{array}{l}{[3,22,} \\
31,32]\end{array}$ \\
\hline
\end{tabular}




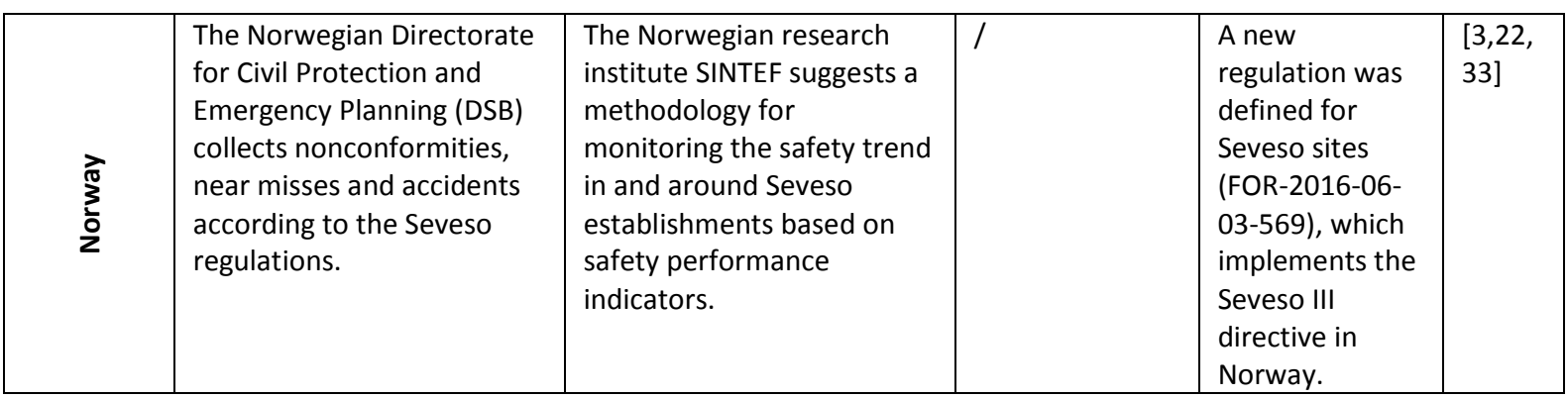

Table 1 reports not only how indicators are used (or suggested), but also how past events are considered. In fact, they are collected by the competent authorities of all EU member and associated countries [3] and may indicate themselves the safety performance of a Seveso site and can be identified as lagging indicators. One of the most complete monitoring approaches is suggested in the United Kingdom, where the competent authorities require systematic collection of past events and safety performance indicators. Such information may be periodically reviewed based on a priority classification of Seveso sites [18-21]. Past events are collected in a publically accessible database in France [26]. Use of safety performance indicators is not mentioned on the national regulations of France and Norway $[25,26,33]$, but is suggested by the French national competence centre for industrial safety and environmental protection (INERIS) [23] and the Norwegian Research institute SINTEF [22]. Both the Italian and Dutch relevant regulations address safety performance monitoring based on indicators and their trends [27,30], and the Dutch National Institute for Public Health and the Environment (RIVM) has drawn up a guidance for use of such indicators [29]. Finally, a different type of indicators are used in Finland, where Seveso sites are also classified based on legislative, technical, operational and organizational elements [31,32].

The quantitative risk assessment (QRA) usually carried out to comply with the Seveso III regulation [3] is performed mainly during the design phase. For this reason, it only describes a static risk picture of the system [34]. This is a limitation because the assessment does not cover the natural evolution and change of an industrial system and does not allow exploiting the growing amount of information from indicators. Villa et al. [34] provides and extensive review on this issue. Khakzad et al. [35-38] have 
extensively worked on the application of Bayesian networks to dynamic risk assessment problems in the chemical process industry. An important contribution to overcome the issue of dynamicity is represented by the recent book on "Dynamic Risk Analysis in the Chemical and Petroleum Industry" [39].

\section{Risk analysis iteration}

The classic "triplet definition of risk" by Kaplan and Garrick [40] states that risk $(R)$ can be expressed by what can go wrong (scenario s), what likelihood it will have (probability $p$ ), and how severe consequences will be (consequence $c$ ):

$R=f(s, p, c)$

Thus, iteration of risk assessment may be performed on three levels by focusing on one of its three variables: $s, p$ or $c$. Identification of accident scenarios is performed as first step of risk analysis (core of risk assessment), as depicted by the NORSOK Standard Z-013 on Risk and Emergency Preparedness Analysis [41] (Figure 1). Probability and consequence are respectively addressed by the risk analysis steps focusing on initiation events and consequences (steps 2 and 3 in Figure 1). Iteration of the three steps would allow continuous update of the risk picture (step 4 in Figure 1) reflecting the real conditions of the establishment. 


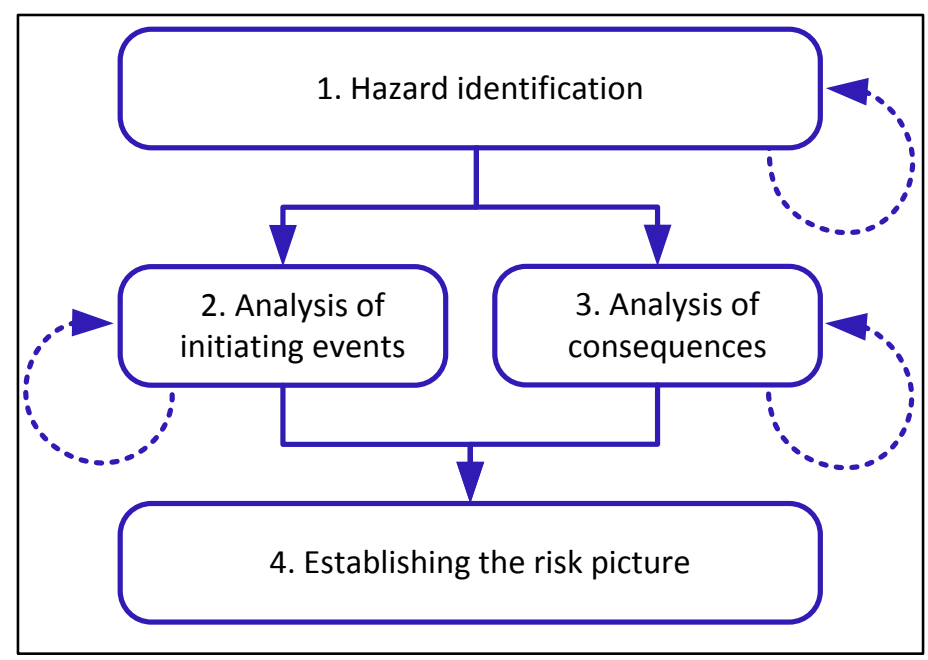

Figure 1 Risk analysis flow chart and suggested iterations

Aven and Krohn [42] suggest including a new dimension in the definition of risk: knowledge (k).

$R=f(s, p, c, k)$

Expressing the level of knowledge used for risk assessment is an intrinsic feature of the calculated value of risk [42]. This gives important insight on how we should treat such result and supports the continuous improvement of the analysis. Despite obvious issues in assessing and representing such knowledge, $k$ represents the driving force of risk analysis iteration.

Paltrinieri and Khan [39] illustrate several methods that may iterate identification accident scenarios, and assessment of probability and consequence (steps 1-3 in Figure 1). This study considers only a selection of them in the perspective of dynamic risk analysis for Seveso sites.

\subsection{Dynamic hazard identification}

As demonstrated by Paltrinieri et al. [43], common hazard identification methods cannot be effectively applied to identify low-probability accidents within a routine hazard identification process. In fact, evidence of new hazards may be obtained from the early deviations or warnings, previously defined as Small Things. The method named Dynamic Procedure for Atypical Scenarios Identification (DyPASI) [43] was specifically developed to continuously improve risk pre-assessment and prepare for atypical accident scenarios. Atypical accident scenarios may be well known to specialists, but not to the 
community of safety professionals, since their occurrence may be very rare or was limited to-date to specific industrial activities [44]. For this reason, dynamic hazard identification assumes a special importance for new or emerging technologies with relative lack of risk experience.

The application of DyPASI entails a systematic screening process of early warnings and risk notions to update hazard identification. The Bow-Tie Analysis approach, such as the one suggested by the Center for Chemical Process Safety [45] or Delvosalle et al. [46], is taken as a basis to develop the methodology. Table 2 reports DyPASI steps. Further details can be found elsewhere $[43,47]$.

Table 2 DyPASI steps. Adapted from [44].

\begin{tabular}{|l|l|l|l|}
\hline Step & Description & Input & Output \\
\hline 0 & $\begin{array}{l}\text { DyPASI requires the application of the conventional bow- } \\
\text { tie technique [45,46] to identify the relevant critical } \\
\text { events. }\end{array}$ & $\begin{array}{l}\text { Input to } \\
\text { conventional } \\
\text { bow-tie analysis. }\end{array}$ & $\begin{array}{l}\text { Bow-tie diagrams } \\
\text { of accident } \\
\text { scenarios. }\end{array}$ \\
\hline 1 & $\begin{array}{l}\text { A search for relevant information concerning undetected } \\
\text { potential hazards is carried out. Search boundaries must } \\
\text { be outlined and quoted in the formulation of the query. } \\
\text { Algorithms can be applied to rank the relevance of the } \\
\text { results obtained [48]. }\end{array}$ & $\begin{array}{l}\text { Information from } \\
\text { accident } \\
\text { databases and } \\
\text { dedicated search } \\
\text { systems. }\end{array}$ & $\begin{array}{l}\text { Risk notions on } \\
\text { undetected } \\
\text { potential hazards. }\end{array}$ \\
\hline 2 & $\begin{array}{l}\text { Determination as to whether data are significant to trigger } \\
\text { further action and proceed with the process of risk } \\
\text { assessment. As a support of this process of prioritization, a } \\
\text { register collecting the risk notions obtained from the } \\
\text { retrieval process and showing their relative relevance and } \\
\text { impact. }\end{array}$ & $\begin{array}{l}\text { Risk notions from } \\
\text { step 1. }\end{array}$ & $\begin{array}{l}\text { Information from } \\
\text { accident } \\
\text { databases and } \\
\text { dedicated search } \\
\text { systems. }\end{array}$ \\
\hline 3 & $\begin{array}{l}\text { Potential scenarios are isolated from the early warnings } \\
\text { gathered and a cause-consequence chain consistent with } \\
\text { the bow-tie diagram is developed. One or more suitable } \\
\text { bow-tie diagrams from step 0 are identified for the process } \\
\text { of integration. }\end{array}$ & $\begin{array}{l}\text { Bow-tie diagrams } \\
\text { from step 0 and } \\
\text { early warnings } \\
\text { from step 2 }\end{array}$ & $\begin{array}{l}\text { Bow-tie diagrams } \\
\text { considering } \\
\text { atypical } \\
\text { scenarios. }\end{array}$ \\
\hline 4 & $\begin{array}{l}\text { Experience on effectiveness and performance of safety } \\
\text { barriers is encompassed in the analysis. Bow-tie diagrams } \\
\text { are completed with safety barriers (technical, operational } \\
\text { and organisational elements which are intended } \\
\text { individually or collectively to reduce possibility/ for a } \\
\text { specific error, hazard or accident to occur, or which limit its } \\
\text { harm/disadvantages [49]). }\end{array}$ & $\begin{array}{l}\text { Integrated bow- } \\
\text { tie diagrams from } \\
\text { step 3. }\end{array}$ & $\begin{array}{l}\text { Safety barriers for } \\
\text { atypical } \\
\text { scenarios. }\end{array}$ \\
\hline
\end{tabular}

\subsection{Dynamic analysis of initiating events}

Hauge et al. [50] have focused their attention on integration of people, organizations, work processes and information technology to make more effective knowledge-based decisions. One of the results obtained has been the development of a technique risk the assessment on a real-time basis: the Risk Barometer. The Risk Barometer is based on definition and real-time monitoring of relevant indicators, 
in order to continuously assess the health of safety barriers and evaluate their probability of failure.

The Norwegian Petroleum Safety Authority defines safety barriers as technical, operational and organizational elements which are intended individually or collectively to reduce possibility/ for a specific error, hazard or accident to occur, or which limit its harm/disadvantages [45]. Indicators describe not only the technical performance of barriers, but also the associated operational and organizational systems. In this way, the Risk Barometer aims to capture early deviations, which may have the potential to facilitate barrier failure and accident occurrence. Thus, the technique objective is performance evaluation of safety barriers and its influence on the overall accident frequency. Barrier performance is related to accident frequency and, in turn, the overall risk picture for evaluation of possible risk fluctuation. Table 3 reports Risk Barometer steps. Further details can be found elsewhere $[50,51]$.

Table 3 Risk Barometer steps.

\begin{tabular}{|c|c|c|c|}
\hline Step & Description & Input & Output \\
\hline 1 & $\begin{array}{l}\text { Definition of major accident scenarios to include in the risk } \\
\text { barometer. This selection should be based on: i) selected } \\
\text { event(s) with significant contribution to the major accident } \\
\text { risk; ii) availability of real time information about related } \\
\text { safety barriers. }\end{array}$ & $\begin{array}{l}\text { Information from } \\
\text { QRA and relevant } \\
\text { personnel. }\end{array}$ & $\begin{array}{l}\text { Major accident } \\
\text { scenarios to } \\
\text { consider. }\end{array}$ \\
\hline 2 & $\begin{array}{l}\text { Identification and review of relevant information sources. } \\
\text { Typical input sources are: QRA, Qualitative and semi- } \\
\text { quantitative barrier analyses, event reports and accident } \\
\text { investigation reports, relevant procedures, and interviews } \\
\text { with experts and personnel. }\end{array}$ & $\begin{array}{l}\text { Various } \\
\text { typologies of } \\
\text { information } \\
\text { sources. }\end{array}$ & $\begin{array}{l}\text { Relevant } \\
\text { information. }\end{array}$ \\
\hline 3 & $\begin{array}{l}\text { Identification of barrier functions and associated barrier } \\
\text { systems related to the defined major accident scenarios. }\end{array}$ & $\begin{array}{l}\text { QRA logic trees } \\
\text { and related } \\
\text { knowledge. }\end{array}$ & $\begin{array}{l}\text { Description of } \\
\text { scenario-related } \\
\text { safety barriers. }\end{array}$ \\
\hline 4 & $\begin{array}{l}\text { Evaluation of the relative importance of safety barriers for } \\
\text { risk based selection of indicators. Sensitivity analysis is } \\
\text { performed on the barriers. }\end{array}$ & $\begin{array}{l}\text { QRA and other } \\
\text { relevant } \\
\text { information. }\end{array}$ & $\begin{array}{l}\text { Risk affecting } \\
\text { safety barriers. }\end{array}$ \\
\hline 5 & $\begin{array}{l}\text { Barrier requirements and factors/ conditions influencing } \\
\text { the overall risk (Risk Influencing Factors - RIFs) should be } \\
\text { taken into account to define barrier indicators. The set of } \\
\text { indicators should be grouped into RIFs and monitor the } \\
\text { fulfilment of barrier requirements. }\end{array}$ & $\begin{array}{l}\text { QRA and other } \\
\text { relevant } \\
\text { information. }\end{array}$ & $\begin{array}{l}\text { Barrier indicators } \\
\text { grouped under } \\
\text { Risk Influencing } \\
\text { Factors. }\end{array}$ \\
\hline 6 & $\begin{array}{l}\text { Aggregation of barrier status information to evaluate } \\
\text { overall risk. Only the most risk-affecting barriers are } \\
\text { considered in the model. Specific aggregation rules are } \\
\text { described in .[51]. }\end{array}$ & $\begin{array}{l}\text { QRA and barrier } \\
\text { indicators. }\end{array}$ & $\begin{array}{l}\text { Risk evaluation } \\
\text { model. }\end{array}$ \\
\hline 7 & $\begin{array}{l}\text { Visualization of the risk picture is established for area level, } \\
\text { barrier function and barriers system performance. }\end{array}$ & $\begin{array}{l}\text { Risk evaluation } \\
\text { model. }\end{array}$ & $\begin{array}{l}\text { Real-time risk risk } \\
\text { diagrams. }\end{array}$ \\
\hline
\end{tabular}




\subsection{Dynamic analysis of consequences}

The event occurred in Seveso was due to the occurrence of a runaway reaction, which is the result of the loss of thermal control in a vessel undergoing a strong exothermic process [52]. Runaway reactions are typically characterized by an exponential increase of the temperature inside the vessel, when the rate of heat generation becomes faster than the rate of heat removal/losses, with a consequent accumulation of heat and acceleration of the reaction rate [53]. This event may be frequent for batch (and semi-batch) chemical processes, in which heat accumulation may occur [54]. Batch processes are mainly used for production of fine and speciality chemicals, which require the manufacturer to be flexible and meet variable market requirements [55]. However, different raw materials and products have different behaviours with respect to the runaway reaction consequence. In addition, safety assessment addressing chemical reactions is mainly based on experimental activity due to the relative complexity of the problem - such phenomena might be yet to be fully understood [52].

A simplified dynamic method aimed at ranking thermal risk was proposed by Casson Moreno et al. [56]. In order to represent risk, runaway reaction severity and probability are defined. Severity of a hazardous material is related to the heat that can be released during the associated runaway reaction. Probability is defined based on reaction evolution, onset temperature of reaction and adiabatic time to maximum rate. The method is based on this minimum set of "hazard parameters" (Table 4) and, cannot only estimate runaway reaction probability on a real-time basis (through reactor temperature), but it also includes the potential consequence. Whenever a new batch process is started, such consequence is updated with new specific reaction features.

Table 4 Definition of hazard parameters [57]

\begin{tabular}{|l|l|}
\hline Onset Temperature ( Tonset $_{\text {) }}$ & Lowest temperature at which exothermic reaction is observed. \\
\hline Time to maximum rate (TMR) & $\begin{array}{l}\text { Time to achieve the maximum self-heating rate under adiabatic } \\
\text { conditions (due to side reactions or decomposition). }\end{array}$ \\
\hline Heat evolved by the reaction $\left(\Delta \mathbf{H}_{\mathbf{R}}\right)$ & Heat produced by an exothermic reaction. \\
\hline
\end{tabular}


Table 5 reports the steps for dynamic assessment of runaway reaction risk. Further details can be found elsewhere [56].

Table 5 Steps for dynamic assessment of runaway reaction risk.

\begin{tabular}{|l|l|l|l|}
\hline Step & Description & Input & Output \\
\hline 1 & Monitor the temperature inside the reactor & Data acquisition. & Reactor temp. \\
\hline 2 & $\begin{array}{l}\text { Calculate the rate of temperature dT/dt and compare it } \\
\text { with a threshold value (depending on the sensitivity of the } \\
\text { equipment). }\end{array}$ & $\begin{array}{l}\text { Reactor } \\
\text { temperature. }\end{array}$ & $\begin{array}{l}\text { Normal operating } \\
\text { conditions or self- } \\
\text { heating mode. }\end{array}$ \\
\hline 3 & $\begin{array}{l}\text { Onset temperature is recorded for self-heating mode. The } \\
\text { adiabatic time to maximum rate is calculated in real time. }\end{array}$ & $\begin{array}{l}\text { Reactor } \\
\text { temperature. }\end{array}$ & $\begin{array}{l}\text { Adiabatic time to } \\
\text { maximum rate. }\end{array}$ \\
\hline 4 & $\begin{array}{l}\text { The ratio of probability is calculated based on a reference } \\
\text { compound congruent with the type of reaction under } \\
\text { analysis. }\end{array}$ & $\begin{array}{l}\text { Adiabatic time to } \\
\text { maximum rate } \\
\text { and reference. }\end{array}$ & $\begin{array}{l}\text { Ratio of } \\
\text { probability. }\end{array}$ \\
\hline 5 & $\begin{array}{l}\text { The ratio of severity is calculated based on a reference } \\
\text { compound congruent with the type of reaction under } \\
\text { analysis. }\end{array}$ & $\begin{array}{l}\text { Heat evolved by } \\
\text { the reaction and } \\
\text { reference. }\end{array}$ & Ratio of severity. \\
& $\begin{array}{l}\text { The thermal risk index is calculated by multiplying the } \\
\text { ratios of probability and severity, and compared with a } \\
\text { predefined risk scale. }\end{array}$ & $\begin{array}{l}\text { Ratios of } \\
\text { probability and } \\
\text { severity. }\end{array}$ & index \\
\hline
\end{tabular}

\section{The Seveso accident and risk analysis progress}

The dioxin discharge that occurred during the Seveso accident came from a rupture disc on a batch plant. The batch process was producing 2,4,5-trichlorophenol (TCP) from 1,2,4,5-tetrachlorobenzene and caustic soda, in the presence of ethylene glycol. At that time, Italian law required the plant to stop for the weekend, even though it was in the middle of a batch. The reaction mixture was at $158^{\circ} \mathrm{C}$, which was below $230^{\circ} \mathrm{C}$, the believed onset temperature. However, today we know that the actual onset temperature is $180^{\circ} \mathrm{C}$. An external coil with exhaust steam was applied to the reactor and could heat the mixture. The coil was from a turbine, which was on reduced load for the weekend, and the steam temperature had risen to about $300^{\circ} \mathrm{C}$. When the stirrer was switched off, the liquid temperature rose to the onset temperature and a slow exothermic reaction started. A considerable amount of dioxin (2,3,7,8-tetrachlorodibenzodioxin or TCDD) formed due to the increasing temperature (runaway reaction). This lead to a rise in pressure and the disc to rupture and the contents of the reactor, about 6 tonnes, including about $1 \mathrm{~kg}$ of dioxin, were distributed over the surrounding area [1]. 
Among the causes of this accident, Kletz [1] indicates lack of hazard identification. He states "if a hazard and operability study (Hazop) had been carried out for all stages of batch and all operating conditions the runaway would not have occurred". Disregarding such scenario since pre-assessment makes this event an atypical accident. This is further demonstrated by the absence in design of catchpots after the relief devices, in order to prevent discharge of hazardous materials in the atmosphere. De Marchi et al. [58] reports that several industrial accidents involving TCP were know to have occurred before the Seveso release. Also Kletz [1] mentions accidents occurred because relief devices discharged in atmosphere instead of catchpot. Such evidence of an atypical accident scenario could have supported the integration of hazard identification by means of a dynamic tool such as DyPASI.

Table 6 Risk notions indicating Seveso accident scenario

\begin{tabular}{|l|l|l|l|l|}
\hline Description & Equipment & Substance & Event & Ref. \\
\hline Monsanto (USA) 1949 & Relief valve & TCP & Release & {$[58]$} \\
\hline BASF (Germany) 1953 & Relief valve & TCP & Release & {$[58]$} \\
\hline Dow Chemical (USA) 1960 & Relief valve & TCP & Release & {$[58]$} \\
\hline Phillips Duphar (Netherlands) 1963 & Relief valve & TCP & Release & {$[58]$} \\
\hline Coalite Chemical Productions (UK) 1968 & Relief valve & TCP & Release & {$[58]$} \\
\hline Frankfurt (Germany) 1993 & Relief valve & Generic chemicals & Release & {$[1]$} \\
\hline
\end{tabular}

DyPASI and the risk notions in Table 6 could have allowed identifying an accident scenario such as the one in Figure 2, which reflects what occurred in Seveso.

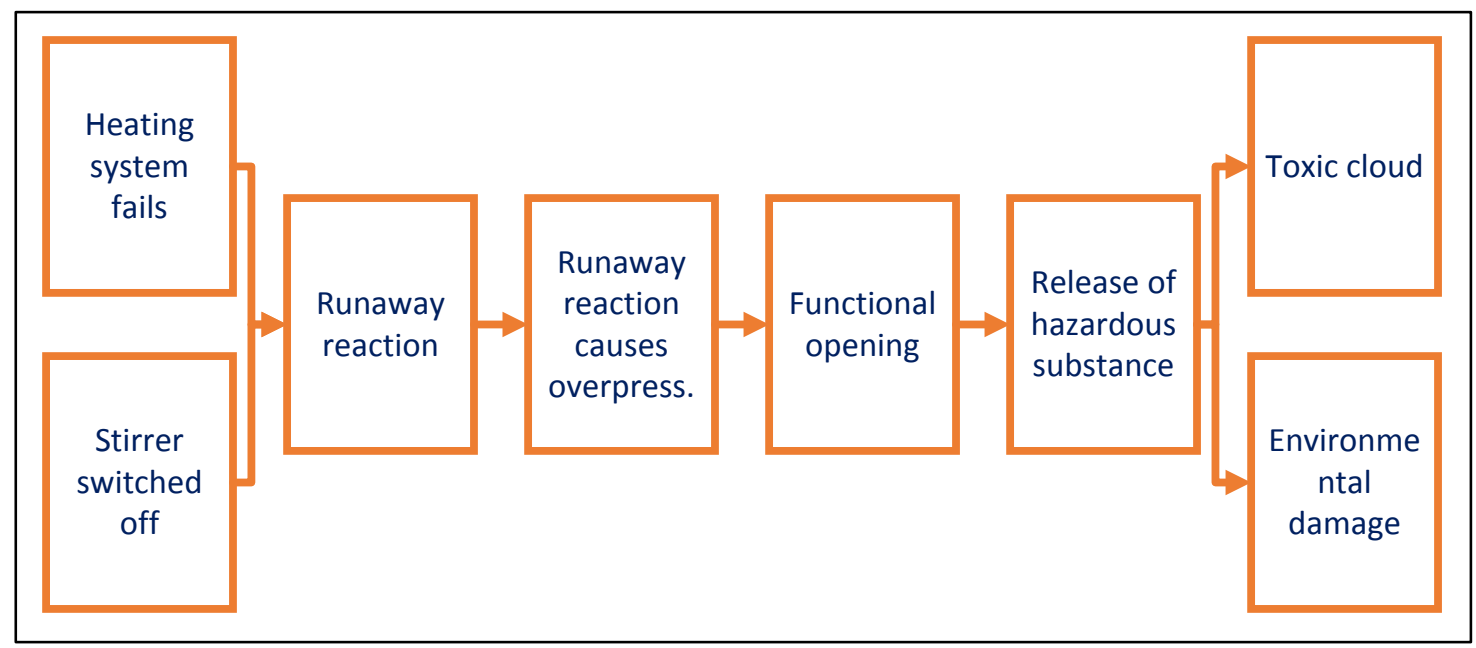

Figure 2 Accident scenario describing release of hazardous material due to runaway reaction 
The accident occurred in Seveso was the result of a series of concurring failures, as pointed out in Lees' Loss Prevention in the Process Industries [59]. For instance, measures of equipment for a number of fundamental parameters was inadequate and led to loss of cooling and agitator failure. Deviations from safe operating procedures were regularly carried out. Management was unable to plan batch processes and comply with the Italian law, requiring shutting down the plant during the weekends.

Such technical, operational and organizational factors could have been partially detected by appropriate indicators, such as the one used by the Risk Barometer. Figure 3 illustrates the relationship between system performance and risk. Small early deviations (Small Things) from the optimal system performance, such as issues related to planning batch processes or unfollowed procedures, can affect the overall risk. For this reason, risk assessment should be regularly iterated by means of tools such as the Risk Barometer. In this way, increasing risk may be early detected and potential accidents may be prevented. Otherwise, unmitigated risks may turn into major accidents such as the one occurred in Seveso.

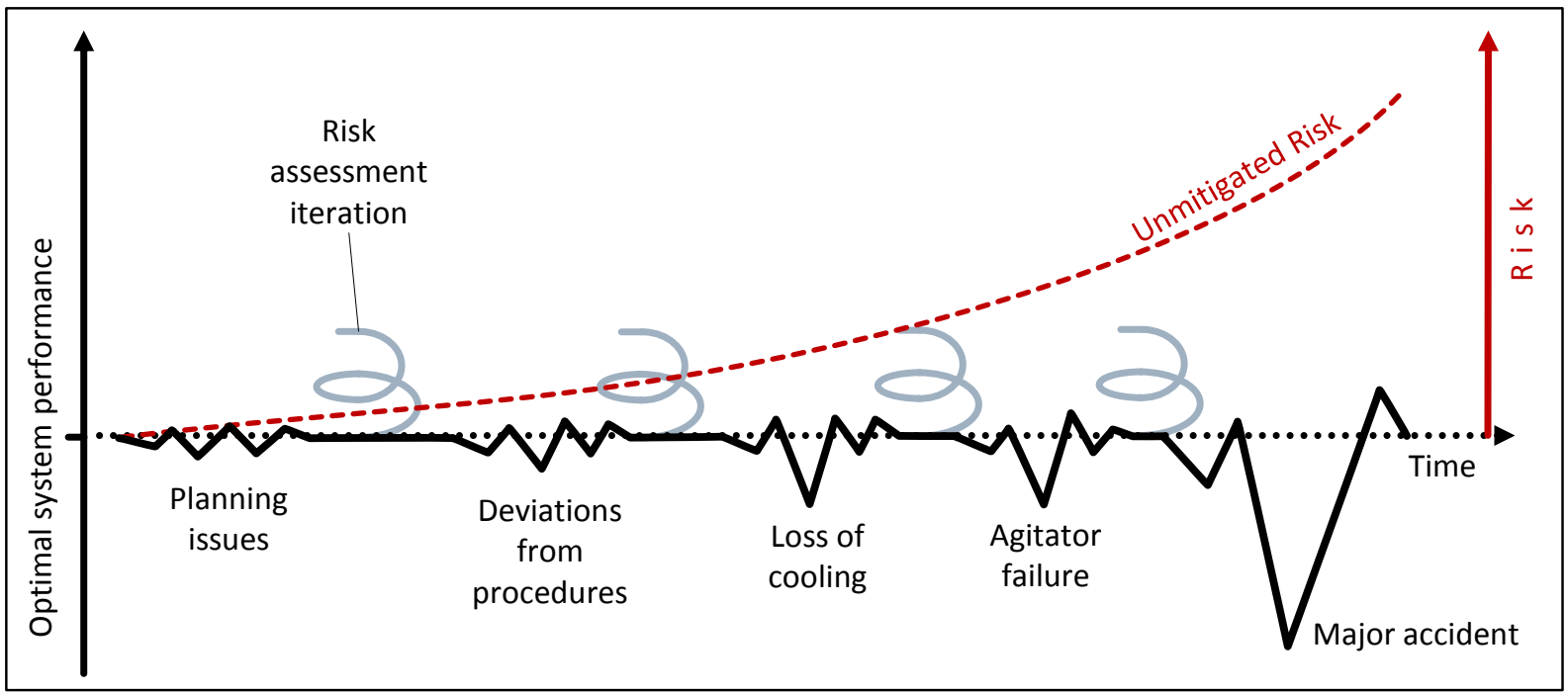

Figure 3 Representation of relationship between system performance monitoring and dynamic risk assessment

Finally, the company was partially aware of the hazardous characteristics of the principal exothermic substances. However, significant variables, such as steam temperature, were not made available to plant operators responsible for the reactor [59]. Such additional heating had a major role in the 
accident and led to the increase of reactor temperature. Reactor temperature readings and results from specific calorimetry tests could have allowed better monitoring of the batch, even when the process was deemed stopped for the weekend. A thermal risk index considering the severity of such reaction would have reported the imminent danger and suggested the personnel to open the cooling system before the release [60].

However, it is impossible to know whether dynamic risk analysis would have prevented the major accident occurred in Seveso. The hypothetical application to this case is only aiming at demonstrating that risk analysis has substantially improved in 40 years of use and lessons have been learned.

\section{Benefits and limitations of dynamic risk analysis}

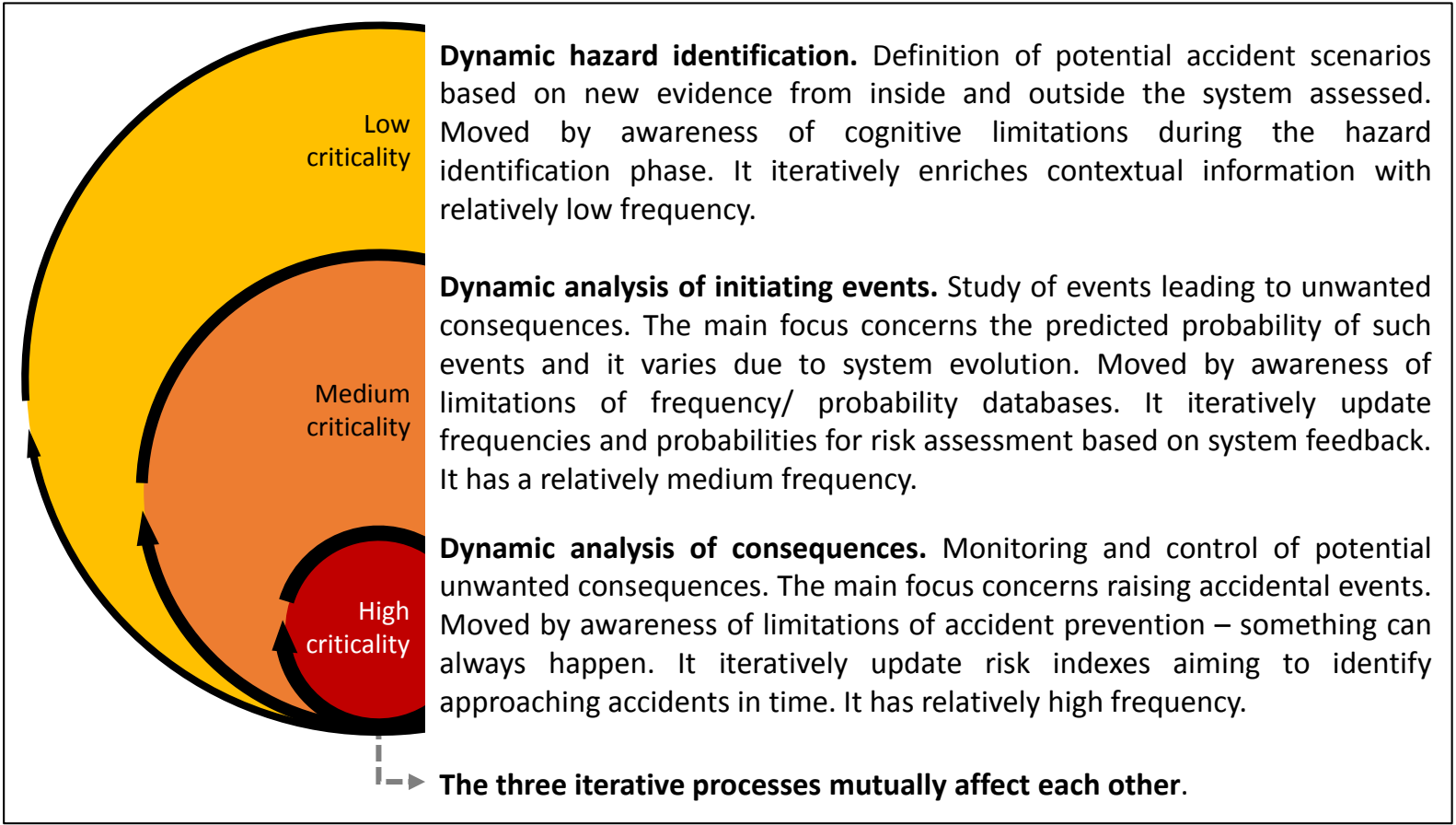

Figure 4 Levels of dynamic risk analysis and related interactions

In this study, dynamic risk analysis is represented by a three-layer approach, as illustrated in Figure 4.

Dynamic hazard identification represents the most external layer, addressing risk pre-assessment. Its criticality is relatively low because a related failure has not the potential to directly lead to an accident. However, it represents the foundation of risk analysis and, for this reason, it requires high solidity. Awareness of cognitive limitations may encourage improvement and iteration of hazard identification, 
in order to include new or emerging evidence of disregarded accident scenarios. For instance, information reported in Table 6 was initially disregarded by Seveso risk analysists, but it could have been considered later and led to integration of the accident scenario depicted in Figure 2. Iteration of hazard identification is performed at a relatively low frequency because new evidence may only occasionally emerge.

Techniques like the Risk Barometer claim to assess risk on a real-time basis. However, they are based on indicators that may not be frequently collected, such as operational and organizational indicators. For this reason, iteration frequency is affected and can be defined as medium when related to the other parts of dynamic risk analysis. Dynamic analysis of initiating events may allow calibrating predicted frequency and probability of unwanted event and overcome the issue of generic databases used for such analyses. For instance, it would have allowed identifying an increasing risk trend in the Seveso plant due to early organizational, operational and technical failures. This provides a proactive feature to the evaluation, whose results are characterized by medium criticality.

High criticality can be associated to dynamic analysis of consequences, due to the vicinity in time with the potential accident. In fact, the thermal risk index can warn of imminent danger and allow for emergency response. Despite the fact that the thermal risk index is truly evaluated on a real time basis through monitoring of reactor temperature, such evaluation concerns mainly runaway probability. In fact, runaway severity is updated only for new reagents, products and, thus, reactions in the batch process. Such approach could have been useful for the Seveso plant where hazardous materials were used in the batch processes.

The three layers mutually affect each other. In fact, introduction of new scenarios would obviously lead to analysis of new initiating events and consequences. In addition, deviations registered by the other parts of dynamic risk analysis may trigger improvement of hazard identification and better description of scenario details. For instance, dynamic analysis of consequences may have allowed for the detection of different features in the potential runaway reaction: the onset temperature for TCP 
production is lower than what believed at the Seveso plant. This could have raised risk awareness and led to improve equipment design by adding a catchpot.

Villa et al. [34] identified specific limitations to dynamic risk analysis techniques:

- No standards are currently available on dynamic risk analysis and applications [61].

- Effectiveness of methods relies on collection of early-warnings, near misses, incidents and accident data [62].

- Most of dynamic risk analysis methodologies (included the ones presented) are part of ongoing studies [63-65].

- Lack of knowledge on dynamic risk analysis methods: no automated software existing, limited experience in industry [64].

- Need of conventional models as pre-requirements (e.g. Bow-Tie analysis for DyPASI and conventional QRA for Risk Barometer) [66].

However, dynamic risk analysis has great potential concerning decision-making support. In fact, current and realistic assessment of risk connected to a certain activity is an important piece of information, which allows deciding how to run such activity or whether to run it at all. Risk informed decisions are used in a number of circumstances where something of value is at stake.

Risk communication (which it ultimately leads back to decision-making) is another important purpose of risk assessment. Participation by multiple parties in information sharing amplifies its benefits, especially when the parties face common risks [67]. The community around a Seveso site has also the right to be informed about associated risks, as mentioned by the Seveso III directive [3]. In addition, competent authorities regularly require data and information on risks and how they are managed.

The industrial system is in continuous evolution and the recipients of risk communication are either part of or tightly connected to it (their requirements may change with time). For this reason, dynamic 
risk analysis may represent the most appropriate approach to not only support critical decisions, but also provide updated and progressively refined risk information.

\section{Conclusions}

Dynamic risk analysis is an emerging approach for continuous evaluation and refinement of the system risk picture. Several techniques have been recently developed. This study introduces three complementary methods addressing dynamic risk analysis on different levels: dynamic hazard identification, dynamic analysis of initiating events, and dynamic analysis of consequences. Their application may produce useful results for risk management within Seveso sites. A representative example of their potential is given by comparing the capabilities the methods with the causes that led to the Seveso catastrophe. It is impossible to say whether the accident could have been prevented, however it demonstrated the progress in risk analysis since then. Dynamic risk analysis may have a series of limitations related to its dependency on data collection or a relatively precocious development. However, it represents an important step forward in the direction of substantial improvement of decision-making support and critical risk communication.

\section{References}

[1] Kletz T. Learning from Accidents. 2001.

[2] European Council. Directive 82/501/EC on the control of major-accident hazards involving dangerous substances - Seveso I. Brussels, Belgium: 1982.

[3] European Parliament And Council. Directive 2012/18/EU of 4 July 2012 on the control of majoraccident hazards involving dangerous substances, amending and subsequently repealing Council Directive 96/82/EC - Seveso III. Off J Eur Union 2012:1-37.

[4] European Council. Council Directive 96/82/EC of 9 December 1996 on the control of majoraccident hazards involving dangerous substances - Seveso II. Brussels, Belgium: Official Journal of the European Communities L10/13; 1996.

[5] Pasman HJ. Risk Analysis and Control for Industrial Processes - Gas, Oil and Chemicals: A System Perspective for Assessing and Avoiding Low-Probability, High-Consequence Events. Elsevier Science; 2015.

[6] Paltrinieri N, Dechy N, Salzano E, Wardman M, Cozzani V. Lessons Learned from Toulouse and Buncefield Disasters: From Risk Analysis Failures to the Identification of Atypical Scenarios Through a Better Knowledge Management. Risk Anal 2012;32. doi:10.1111/j.1539- 
6924.2011.01749.x.

[7] Paltrinieri N, Dechy N, Salzano E, Wardman M, Cozzani V. Towards a new approach for the identification of atypical accident scenarios. J Risk Res 2013;16. doi:10.1080/13669877.2012.729518.

[8] Taleb NN. The black swan: the impact of the highly improbable. 2007. doi:10.5465/AMP.2011.61020810.

[9] Paté-Cornell E. On "Black Swans" and "Perfect Storms": Risk Analysis and Management When Statistics Are Not Enough. Risk Anal 2012;32:1823-33. doi:10.1111/j.1539-6924.2011.01787.x.

[10] Haugen S, Vinnem JE. Perspectives on risk and the unforeseen. vol. 137. 2015. doi:10.1016/j.ress.2014.12.009.

[11] Sornette D. Dragon-kings, black swans, and the prediction of crises. Int J Terrasp Sci Eng 2009;2:1-18.

[12] Weatherall JO. The physics of wall street: a brief history of predicting the unpredictable. 2012.

[13] Sornette A, Sornette D. Self-Organized Criticality and Earthquakes. Europhys Lett 1989;9:197202. doi:10.1209/0295-5075/9/3/002.

[14] Paltrinieri N, Oien K, Cozzani V. Assessment and comparison of two early warning indicator methods in the perspective of prevention of atypical accident scenarios. Reliab Eng Syst Saf 2012;108:21-31. doi:10.1016/j.ress.2012.06.017.

[15] Paltrinieri N, Oien K, Tugnoli A, Cozzani V. Atypical accident scenarios: From identification to prevention of underlying causes. vol. 31. 2013. doi:10.3303/CET1331091.

[16] Paltrinieri N, Khan F. Chapter 2 - New Definitions of Old Issues and Need for Continuous Improvement. Dyn. Risk Anal. Chem. Pet. Ind., 2016, p. 13-21. doi:10.1016/B978-0-12-8037652.00002-0.

[17] Øien K, Utne IB, Herrera IA. Building Safety indicators: Part 1 - Theoretical foundation. Saf Sci 2011;49:148-61. doi:10.1016/j.ssci.2010.05.012.

[18] UK Secretary of State. COMAH - The Control of Major Accident Hazards Regulations - 2015 No. 483 2015:44.

[19] HSE. The Control of Major Accident Hazards (COMAH) Regulations. Third. London: Health and Safety Executive (HSE); 2015.

[20] COMAH Competent Authorities. Site Prioritisation Methodology. Bootle, UK: 2013.

[21] COMAH Competent Authorities. Process safety performance indicators (Operational Delivery Guide). Bootle, United Kingdom: 2012.

[22] Tinmannsvik RK, Hokstad P, Paltrinieri N. Methodology for monitoring safety level development in and around Seveso establishments. Trondheim, Norway: 2013.

[23] INERIS. Pilotage de la sécurité par les indicateurs de performance. Verneuil En Halatte, France: 2015.

[24] Ministère de l'écologie du développement durable et de l'énergie. Décret no 2014-284 du 3 mars 2014 modifiant le titre ler du livre V du code de l'environnement. J Off La République Fr 2014.

[25] Ministère de l'écologie du développement durable et de l'énergie. Décret no 2014-285 du 3 
mars 2014 modifiant la nomenclature des installations classées pour la protection de l'environnement. J Off La République Fr 2014.

[26] French Ministry of Ecology Sustainable Development and Energy. ARIA (analysis, research and information on accidents) 2016. http://www.aria.developpement-durable.gouv.fr/.

[27] Consigio dei Ministri. Decreto legislativo 26 giugno 2015, n. 105. Gazz Uff 2015.

[28] Alberto R. Workshop P - Direttiva Seveso: presente e futuro degli stabilimenti a rischio di incidente rilevante 2015 .

[29] Sol VM, Bollen LAA, Kooi ES, Manuel HJ. Handreiking voor inspectie van Brzo-bedrijven. Bilthoven, The Netherlands: 2015.

[30] Staatssecretaris van Infrastructuur en Milieu. Besluit risico's zware ongevallen 2015. Overheid 2015.

[31] Valtioneuvosto. Asetus vaarallisten kemikaalien käsittelyn ja varastoinnin valvonnasta 21.5.2015/685 2015.

[32] Tukes. Periodical inpsection - agenda. Helsinki, Finland: 2005.

[33] Justis- og beredskapsdepartementet. Forskrift om tiltak for å forebygge og begrense konsekvensene av storulykker i virksomheter der farlige kjemikalier forekommer (storulykkeforskriften). LOVDATA 2016.

[34] Villa V, Paltrinieri N, Khan F, Cozzani V. Towards dynamic risk analysis: A review of the risk assessment approach and its limitations in the chemical process industry. Saf Sci 2016;89:7793. doi:http://dx.doi.org/10.1016/j.ssci.2016.06.002.

[35] Khakzad N, Khan F, Amyotte P. Dynamic risk analysis using bow-tie approach. Reliab Eng Syst Saf 2012;104:36-44.

[36] Khakzad N, Khan F, Paltrinieri N. On the application of near accident data to risk analysis of major accidents. Reliab Eng Syst Saf 2014;126. doi:10.1016/j.ress.2014.01.015.

[37] Khakzad N, Khan F, Amyotte P. Quantitative risk analysis of offshore drilling operations: A Bayesian approach. Saf Sci 2013;57:108-17. doi:10.1016/j.ssci.2013.01.022.

[38] Khakzad N, Khan F, Amyotte P. Dynamic safety analysis of process systems by mapping bow-tie into Bayesian network. Process Saf Environ Prot 2013;91:46-53. doi:10.1016/j.psep.2012.01.005.

[39] Paltrinieri N, Khan F. Dynamic Risk Analysis in the Chemical and Petroleum Industry: Evolution and Interaction with Parallel Disciplines in the Perspective of Industrial Application. Elsevier Science; 2016.

[40] Kaplan S, Garrick BJ. On The Quantitative Definition of Risk. Risk Anal 1981;1:11-27. doi:10.1111/j.1539-6924.1981.tb01350.x.

[41] NORSOK. Standard Z-013, Risk and Emergency Preparedness Analysis. Third Edit. Lysaker, Norway: Standards Norway; 2010.

[42] Aven T, Krohn BS. A new perspective on how to understand, assess and manage risk and the unforeseen. Reliab Eng Syst Saf 2014;121:1-10. doi:10.1016/j.ress.2013.07.005.

[43] Paltrinieri N, Tugnoli A, Buston J, Wardman M, Cozzani V. Dynamic Procedure for Atypical Scenarios Identification (DyPASI): A new systematic HAZID tool. J Loss Prev Process Ind 2013;26:683-95. doi:10.1016/j.jlp.2013.01.006. 
[44] Paltrinieri N, Tugnoli A, Cozzani V. Hazard identification for innovative LNG regasification technologies. Reliab Eng Syst Saf 2015;137:18-28. doi:10.1016/j.ress.2014.12.006.

[45] CCPS. Guidelines for Chemical Process Quantitative Risk Analysis. Second. New York: Center for Chemical Process Safety of the American Institute of Chemical Engineers; 2000.

[46] Delvosalle C, Fievez C, Pipart A, Debray B. ARAMIS project: a comprehensive methodology for the identification of reference accident scenarios in process industries. J Hazard Mater 2006;130:200-19. doi:10.1016/j.jhazmat.2005.07.005.

[47] Paltrinieri N, Tugnoli A, Cozzani V. Chapter 4 - Dynamic Hazard Identification: Tutorial and Examples. Dyn. Risk Anal. Chem. Pet. Ind., 2016, p. 37-48. doi:10.1016/B978-0-12-8037652.00004-4.

[48] Zhao J, Cui L, Zhao L, Qiu T, Chen B. Learning HAZOP expert system by case-based reasoning and ontology. Comput Chem Eng 2009;33:371-8. doi:10.1016/j.compchemeng.2008.10.006.

[49] Petroleum Safety Authority. Principles for barrier management in the petroleum industry. Stavanger, Norway: 2013.

[50] Hauge S, Okstad E, Paltrinieri N, Edwin N, Vatn J, Bodsberg L. Handbook for monitoring of barrier status and associated risk in the operational phase, the risk barometer approach. SINTEF F27045. Trondheim, Norway: 2015.

[51] Scarponi GE, Paltrinieri N, Khan F, Cozzani V. Chapter 7 - Reactive and Proactive Approaches: Tutorials and Example. Dyn. Risk Anal. Chem. Pet. Ind., 2016, p. 75-92. doi:10.1016/B978-0-12803765-2.00007-X.

[52] Stoessel F. Thermal Saftey of Chemical Processes. Weinheim: 2008.

[53] Varma A, Morbidelli M, Wu H. Parametric sensitivity in chemical systems. Cambridge University Press; 2005.

[54] Copelli S, Torretta V, Pasturenzi C, Derudi M, Cattaneo CS, Rota R. On the divergence criterion for runaway detection: Application to complex controlled systems. J Loss Prev Process Ind 2014;28:92-100. doi:10.1016/j.jp.2013.05.004.

[55] Rippin DWT. Batch process systems engineering: A retrospective and prospective review. Comput Chem Eng 1993;17:S1-13. doi:10.1016/0098-1354(93)80201-W.

[56] Casson Moreno V, Salzano E, Khan F. Chapter 11 - Assessing the Severity of Runaway Reactions. Dyn. Risk Anal. Chem. Pet. Ind., 2016, p. 127-38. doi:10.1016/B978-0-12-803765-2.00011-1.

[57] Group HW. HarsBook: A Technical Guide for the Assessment of Highly Reactive Chemical Systems. DECHEMA; 2002.

[58] De Marchi B, Funtowicz S, Ravetz J. Seveso: A paradoxical classic disaster. Long Road to Recover Community Responses to Ind Disaster 1996:86-120.

[59] Sam Mannan. Lees' Loss Prevention in the process industries. vol. 1. Butterworth-Heinemann, Elsevier; 2005.

[60] Mocarelli P. Seveso: a teaching story. Chemosphere 2001;43:391-402.

[61] Paltrinieri N, Khan F, Amyotte P, Cozzani V. Dynamic approach to risk management: Application to the Hoeganaes metal dust accidents. Process Saf Environ Prot 2014;92:669-79. doi:10.1016/j.psep.2013.11.008.

[62] Khakzad N, Khan F, Paltrinieri N. On the application of near accident data to risk analysis of 
major accidents. Reliab Eng Syst Saf 2014;126:116-25. doi:10.1016/j.ress.2014.01.015.

[63] Paltrinieri N, Khan F, Cozzani V. Coupling of advanced techniques for dynamic risk management. J Risk Res 2014:1-21. doi:10.1080/13669877.2014.919515.

[64] Pasman HJ, Rogers WJ. Bayesian networks make LOPA more effective, QRA more transparent and flexible, and thus safety more definable! J Loss Prev Process Ind 2013;26:434-42. doi:10.1016/j.jlp.2012.07.016.

[65] Paltrinieri N, Hokstad P. Dynamic risk assessment: Development of a basic structure. Saf. Reliab. Methodol. Appl. - Proc. Eur. Saf. Reliab. Conf. ESREL 2014, Wroclaw, Poland: 2015, p. 1385-92. doi:10.1201/b17399-191.

[66] Paltrinieri N, Scarponi G. Addressing Dynamic Risk in the Petroleum Industry by Means of Innovative Analysis Solutions. Chem Eng Trans 2014;36:451-6. doi:10.3303/CET1436076.

[67] Phimister JR, Bier VM, Kunreuther HC. Accident precursor analysis and management: reducing technological risk through diligence. National Academies Press; 2004. 